\title{
Pemberdayaan UMKM Gerabah Melalui Pembentukan Komunitas Pra-Koperasi Di Kabupaten Ponorogo
}

\author{
Sri Umi Mintarti Widjaja1, Dian Rachmawati², Syahrul Munir ${ }^{3}$, Yogi Dwi Satrio \\ 1,2,3,4,Universitas Negeri Malang \\ ${ }^{4}$ Program Studi Pendidikan Ekonomi, Fakultas Ekonomi, Universitas Negeri Malang

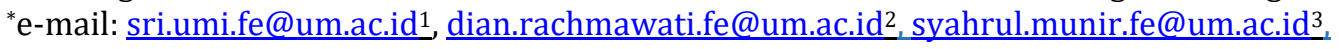 \\ yogi.dwi.fe@um.ac.id ${ }^{4}$
}

\begin{abstract}
Problems that occur in clay craftsmen in Plancungan Village, Ngloning Village and Gombang Village, Slahung District, Ponorogo Regency include lack of capital, lack of marketing networks and low product innovation, and lack of regeneration in this business. So as to overcome these problems is done by providing training and the formation of pre-cooperatives for the craftsmen. The purpose of this service is to improve the quality of human resources and promote the existence of earthenware vessels. Community service activities are carried out by forming a pre-cooperative community in order to facilitate the availability of capital for craftsmen. In addition, there will also be some marketing training and training to increase product innovation so that it has added value and innovation that is in line with the needs of the times. Both of these trainings were carried out by marketing practitioners and from the industry department and cooperatives of Ponorogo Regency.
\end{abstract}

Keywords: SMEs, Pottery, Community, Pre-Cooperative

\begin{abstract}
Abstrak
Permasalahan yang terjadi pada pengrajin tanah liat di Desa Plancungan, Desa Ngloning dan Desa Gombang Kecamatan Slahung Kabupaten Ponorogo antara lain kurangnya permodalan, kurangnya jaringan pemasaran dan rendahnya inovasi produk, serta tidak adanya regenerasi dalam usaha ini. Sehingga untuk mengatasi permasalah tersebut dilakukan dengan memberikan pelatihan dan pembentukan pra-koperasi bagi warga pengrajin. Tujuan pengabdian ini untuk meningkatkan kualitas sumberdaya manusia dan mengangkat eksistensi UMKM gerabah. Kegiatan pengabdian dilakukan dengan membentuk sebuah komunitas pra-koperasi agar mempermudah ketersediaan modal bagi para pengrajin. Selain itu juga akan dilakukan beberapa pelatihan pemasaran dan pelatihan peningkatan inovasi produk yang dihasilkan supaya memiliki nilai tambah dan inovasi yang sesuai dengan kebutuhan zaman. Kedua pelatihan tersebut dilakukan oleh praktisi pemasaran dan dari dinas perindustrian dan koperasi Kabupaten Ponorogo.
\end{abstract}

Kata kunci: UMKM, Gerabah, Komunitas, Pra Koperasi

\section{PENDAHULUAN}

Perguruan tinggi sebagai agent of change, salah satunya Universitas Negeri Malang (UM) berusaha mengupayakan salah satu bentuk Tri Dharma Perguruan Tinggi dengan mengembangkana program Kewirausahaan. Salah satu keberhasilannya yaitu keberhasilan mahasiswa UM menyabet juara 2 kategori teknologi dalam ajang ekspo Kewirausahaan Mahasiswa Indonesia (KMI) IX 2018 yang diselenggarakan di Kampus Darmaga Institut Pertanian Bogor (IPB) (9-12/11) dan mengusung tema Penguatan Wirausaha Mahasiswa Indonesia melalui Techno-Sociopreneurship menghadapi Revolusi Industri 4.0. KMI merupakan salah satu program kewirausahaan untuk mahasiswa dari Direktorat Pembelajaran dan Kemahasiswaan Kementerian Riset, Teknologi dan Pendidikan Tinggi sekaligus ajang pertemuan mahasiswa wirausaha se-Indonesia yang telah dibekali dengan pengetahuan, keterampilan dan sikap atau jiwa wirausaha.

Data Dinas Koperasi dan UMKM tahun 2012 menunjukkan total nilai Produk Domestik Bruto (PDB) Indonesia mencapai Rp. 8.241,8 triliun seperti terlihat pada tabel 1.1. UMKM memberikan kontribusi sebesar Rp. 4.869,5 triliun atau 59,08\% dari total PDB Indonesia. Jumlah populasi UMKM Indonesia pada tahun 2012 mencapai 56,53 juta unit usaha atau 99,99\% terhadap total unit usaha di Indonesia, sementara jumlah tenaga kerjanya mencapai 107,65 juta 
orang atau 97,16\% terhadap seluruh tenaga kerja Indonesia. Data tersebut menunjukkan bahwa peranan UMKM dalam perekonomian Indonesia sangat penting dalam menyediakan lapangan pekerjaan dan menghasilkan output yang berguna bagi masyarakat.

Industri gerabah merupakan salah satu industri kreatif yang berkembang di Indonesia. Industri kreatif di Indonesia merupakan industri yang mampu bertahan di Era krisis moneter 1997, bahkan menjadi penopang laju roda perekonomian di Indonesia. Hal ini dibuktikan dengan capaian nilai Ekpor Indonesia yang melampaui USD25,4 juta pada 2018, nilainya lebih tinggi dibanding tahun sebelumnya yang menembus USD25,2 juta (Kemenperin, 2018)

Selain memiliki peran yang positif dalam pertumbuhan ekonomi dan penyerapan tenaga kerja, UMKM juga berperan dalam pendistribusian hasil-hasil pembangunan sehingga UMKM mampu mendukung pemerataan hasil pembangunan ekonomi. Keberadaan sektor Usaha Mikro, Kecil, dan Menengah bukan hanya dianggap sebagai tempat penampungan sementara bagi para pekerja yang belum masuk ke sektor formal, tetapi juga sebagai motor pertumbuhan aktivitas ekonomi. Sehingga pengembangan dan pemberdayaan UMKM menjadi pilihan strategis untuk meningkatkan pendapatan kelompok masyarakat berpendapatan rendah, dalam rangka mengurangi kesenjangan pendapatan dan kemiskinan melalui peningkatan kapasitas usaha dan keterampilan pengelolaan usaha.

Berdaarkan fakta yang termuat dalam Sindonews.com (17 Agustus 2018) menunjukkan bahwa Sektor Usaha Mikro Kecil dan Menengah (UMKM) berkontribusi besar terhadap perekeonomian Jawa Timur (Jatim). Tercatat pada semester I 2018, pertumbuhan ekonomi Jatim mencapai 5,57\% dengan PDRB Atas Dasar Harga Berlaku (ADHB) mencapai Rp544,44 triliun. Capaian tersebut karena dukungan dari UMKM di Jatim. Gubernur Jatim Soekarwo mengatakan, dalam Sindonews.com, bahwa kontribusi UMKM terhadap perekonomian Jatim juga mengalami peningkatan. Tahun 2012, UMKM berkontribusi terhadap PDRB sebesar 54,98\%. Dengan asumsi ceteris paribus, maka kontribusi UMKM terhadap PDRB Jatim tahun 2016 naik menjadi 57,52\%. Serta Berdasarkan sensus ekonomi nasional, populasi UMKM Jatim tumbuh dari 6,8 juta pada yahun 2012, menjadi 9,59 juta pada 2017. Jumlah sebaran UMKM yang cukup signifikan di wilayah Jaw Timur menunjukkan bahwa UMKM menjadi salah satu tulang punggung pendapatan daerah provinsi Jawa Timur yang harus terus dikembangkan dan diberdayakan.

Kerajinan sebagai salah satu produk usaha mikro kecil menengah yang cukup diminati oleh masyarakat, seperti kerajinan rotan, kerajinan bamboo serta kerajinan keramik maupun tanah liat. Kerajinan dari tanah liat dan keramik ini sering disebut dengan istilah gerabah dan tembikar. Namun, pada praktiknya kerajinan gerabah tradisional tanah liat mengalami pergeseran. Tidak hanya pergeseran persediaan di pasaran yang semakin menurun karena permintaan masyarakat yang digantikan oleh alumunian, tembaga perak maupun gerabah keramik. Turunnya permintaan ini disebabkan oleh rendahnya kualitas dan inovasi gerabah tanah liat yang dihasilkan oleh pengrajin UMKM gerabah.

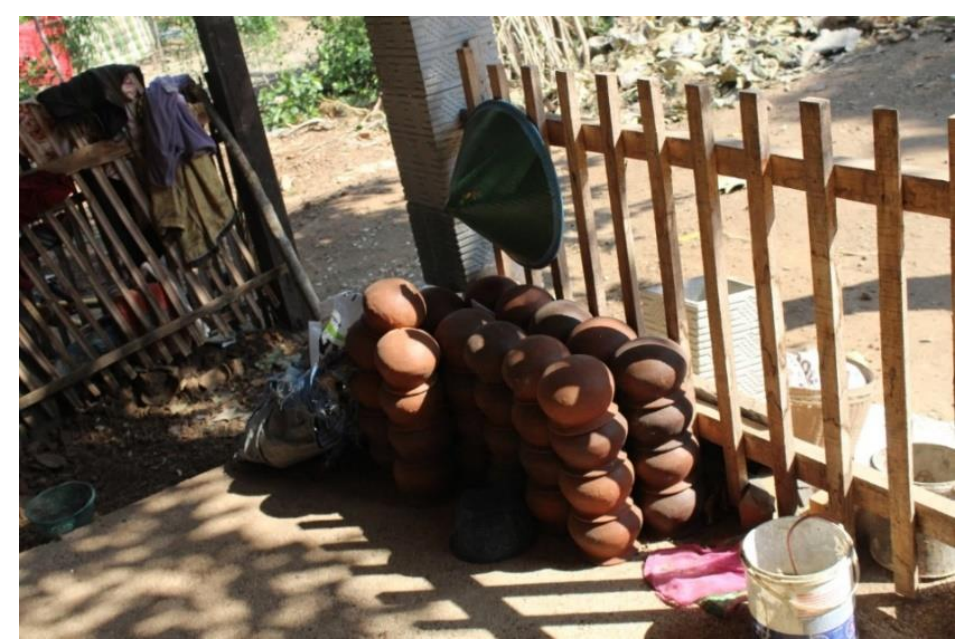

Gambar 1. Gerabah produk yang dihasilkan pengrajin di desa Plancungan 


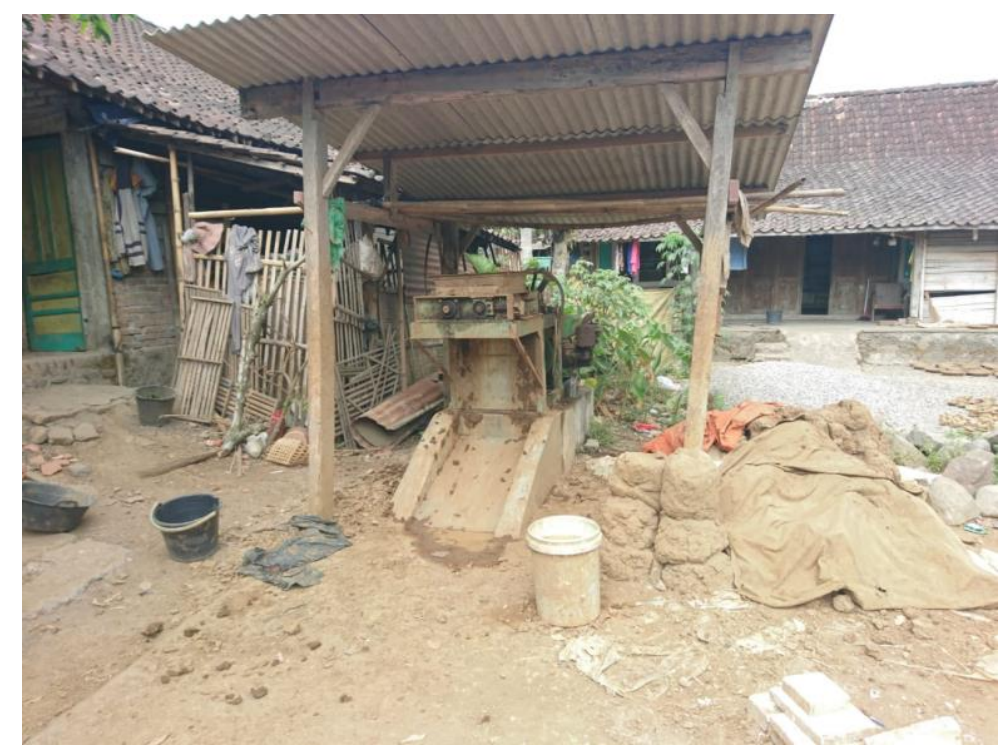

Gambar 2. Peralatan yang digunakan gerabah pengrajin di desa Plancungan

Kabupaten Ponorogo merupakan salah satu kabupaten di wilayah provinsi Jawa Timur yang mennjadi produsen gerabah tanah liat, terutama di wilayah selatan yaitu Kecamatan Slahung. Akan tetapi jenis produk yang dihasilkan masih sangat sederhana. Selain kegiatan produksi yang masih sangat sederhana, kualitas yang masih sangat cukup sederhana, produk gerabah tanah liat yang dihasilkan juga tidak memiliki nilai jual yang lebih. Produk gerabah tanah liat yang dihasilkan belum memiliki nilai juag yang lebih dengan menambah kreativitas dan inovasi produk, hal ini menyebabkan harga gerabah tanah liat di pasaran masih sangat rendah. Rendahnya harga di pasaran juga akan menurunkan pendapatan pedagang dan pengrajin gerabah, umumnya stagnasi harga terjadi pada pelaku ekonomi pertama yaitu produsen atau pengrajin gerabah tanah liat.

Dalam perjalanan UMKM gerabah yang ada di wilayah Kabupaten Ponorogo, khususnya adalah Kecamatan Slahung yaitu tidak adanya kelompok atua komunitas pengrajin gerabah sehingga komunikasi dan koordinasi antar pengrajin masih sangat rendah. Keberadaan komunitas tidak hanya digunakan sebagai wadah komunikasi dan koordinasi, tetapi juga menjadi wadah belajar untuk berbagi pengetahun dan keterampilan sehingga apabila pengrajin terkumpul dalam suatu wadah atau komunitas dapat berbagi ide dan wawasan dalam meningatkan keterampilan untuk menghasilkan produk gerabah tanah liat yang lebih berkualitas. Selain hal tersebut, keberadaan komunitas pengrajin gerabah dapat digunakan sebagai wadah musyawarah pengrajin untuk menentukan harga sehingga penentuan harga dilakukan secara bersama.

Slahung merupakan salah satu kecamatan di kabupaten Ponorogo yang memiliki sejumlah unit usaha mikro kecil menengah (UMKM) kerajinan Gerabah yang hingga kini terus bertahan, Menurut warga sekitar Industri Gerabah ini sudah menjadi mata pencaharian secara turuntemurun sehingga boleh dikatakan kerajinan gerabah ini merupakan kekayaan lokal bagi daerah Ponorogo.

Berdasarkan data statistik kabupaten Ponorogo (BPS, (2018)), data seluruh pengrajin gerabah pada tahun 2017 adalah 160 unit usaha. Sedangkan dari hasil survei lapangan di 3 desa di kecamatan Slahung, yaitu desa Plancungan, Ngloning, dan Gombang, menunjukkan bahwa terdapat lebih dari 40 Pengrajin yang tetap bertahan, dengan usia rata-rata pekerja di atas 40 tahun. Para pengrajin yang kebanyakan adalah kaum wanita, hingga kini masih terus menekuni usaha kerajinan gerabah mereka meskipun boleh dibilang hasilnya tidak seberapa.

Berdasarkan fakta dan permasalahan di atas, maka pengembangan dan pemberdayaan pelaku usaha mikro kecil dan menengah gerabah tradisional yang berbasis komunitas sangat diperlukan. Selain itu, mengingat UMKM merupakan usaha yang secara langsung menyentuh 
masyarakat Indonesia, maka pembentukan komunitas didasarkan pada landasan ekonomi bangsa yaitu ekonomi pancasila atau ekonomi kerakyatan. Sehingga dalam hal ini peneliti bermaksud untuk melakukan pengabdian dan penelitian pada pengrajin gerabah tradisioanl tanah liat dengan judul "Pemberdayaan Pengrajin UMKM Gerabah Melalui Pembentukan Komunitas Berbasis Ekonomi Kerakyatan di Kawasan Pedesaan Kecamatan Slahung Kabupaten Ponorogo."

\section{METODE}

Pada dasarnya pengabdian masyarakat ini dilakukan dengan metode DBR atau Development Based Riset sehingga pemberdayaan dilakukan setelah adanya penelitian terdahulu. Penelitian awal dilakukan untuk mengenali permasalahan yang terjadi pada subjek penelitian, sehingga model pemberdayaan yang dilakukan juga sesuai dengan permasalahan dan mampu memberikan solusi dari permasalahan yang ada.

Penelitian ini menggunakan pendekatan kualitatif dengan jenis penelitian fenomenologi. Penelitian ini diangkat dari fenomena yang terjadi di desa Plancungan, desa Ngloning dan desa Gombang kecamatan Slahung kabupaten Ponorogo, dengan subjek penelitian para pengrajin gerabah. Metode yang digunakan dalam mengumpulkan data pada penelitian ini antara lain 1) Melakukan observasi ke para pengrajin gerabah, 2) melakukan wawancara mandalam dengan pihak-pihak terkait (pengrajin gerabah, pedagang gerabah, dan pemerintah), 3) dokumentasi, serta 4) melakukan focus group discussion (FGD). Data yang telah dikumpulkan kemudian dianalisis dengan Teknik Analisis data yang diadopsi dari pemikiran Stevick, Colaizzi, dan Keen yaitu 1) Mendeskripsikan fenomena yang ditemui di pengrajin gerabah (tahap awal); 2) Menginventarisasi pernyataan-pernyataan penting yang relevan dengan fenomena yang ditemui dipengrajin gerabah (Tahap Horizonalization); 3) Mengklasifikasikan (mereduksi) pernyataanpernyataan ke dalam tema-tema yang bermakna dan menyisihkan (mengeliminasi) penyataan yang tumpang tindih/ berulang-ulang/ tidak jelas (Tahap Cluster of Meaning); 4) Melakukan refleksi terhadap hasil deskripsinya (tahap validasi dan labeling); 5) Membuat deskripsi makna dan esensi pengalaman secara keseluruhan (tahap pembuatan Individual Textural Description/ IDT) (Creswell, 1998), (Moustakas, 1994). Untuk meyakinkan keabsahan data hasil penelitian, peneliti melakukan triangulasi sumber yaitu dengan mengecek dan membandingkan jawaban penelitian kepada beberapa narasumber.

Survei awal dilakukan dengan melakukan wawancara mendalam dan dokumentasi secara langsung kepada beberapa informan yang terkait yaitu pengrajin gerabah, pedagang gerabah, pemerintah setempat, dengan membuat FGD atau Forum Group Discussion. Melalui kegaitan FGD tersebut dikoordinasikan untuk merumuskan solusi awal berupa pembentukan komunitas PraKoperasi, dilanjutkan dengan pelatihan pemasaran dan pelathan inovasi produk untuk meningkatkan nilai ekonomi dari produk gerabah tersebut. Tahapan pelaksanaan kegiatan tersebut tertuang dalam gambar di bawah ini. 


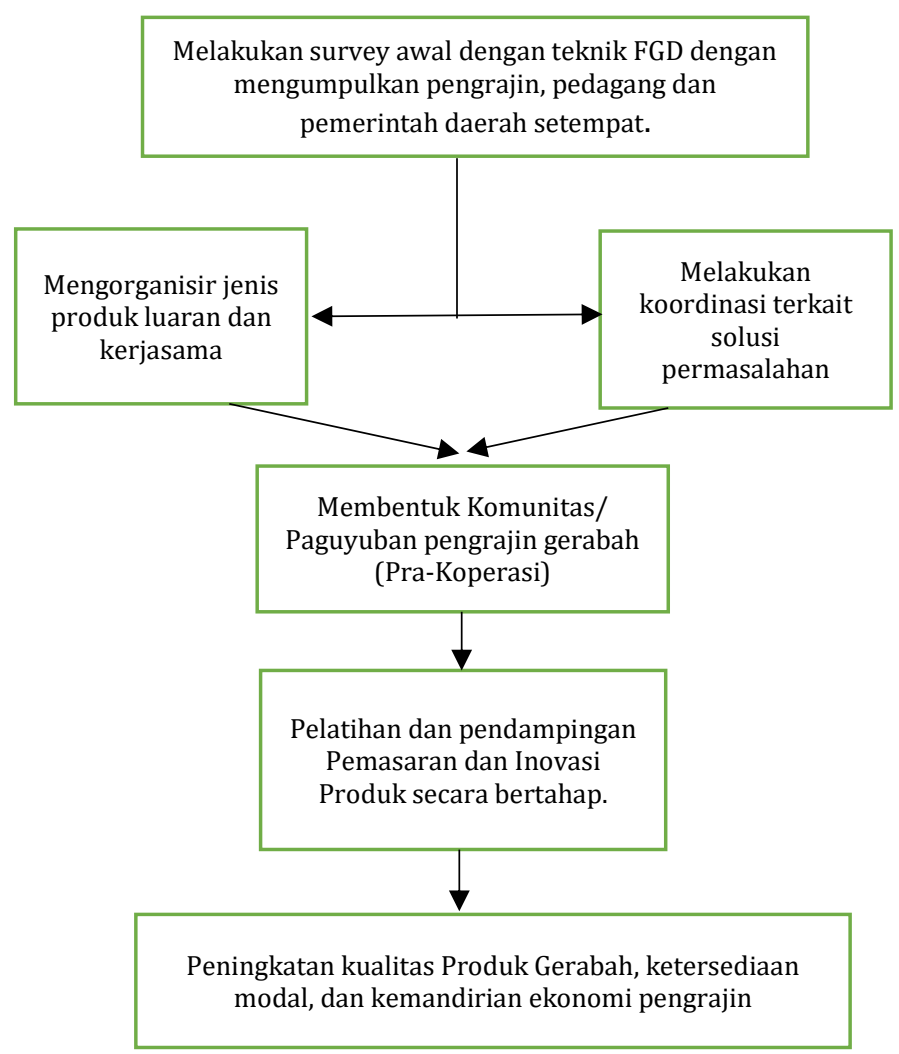

Gambar 3. Metode Pelaksanaan Kegiatan Pengabdian Kepada Masyarakat

\section{HASIL DAN PEMBAHASAN}

Berdasarkan hasil survey dan FGD yang dilakukan pada para stake holder, uraian permasalahan pada pengrajin gerabah di kawasan Kecamatan Slahung Kabupaten Ponorogo, adalah sebegai berikut;

a. Permasalahan permodalan, alternative solusi yang ditawarkan adalah dengan pembentukan pra-koperasi atau dalam jangka pendek dapat melakukan kerja sama dengan pemerintah desa untuk memanfaatkan dana desa sementra dalam upaya pengembangan UMKM gerabah tanah liat pada desa setempat.

b. Permasalahan pemasaran, jaringan pemasaran produk dikuasai oleh para tengkulak, sehingga tengkulak berani memainkan harga yang sangat rendah terhadap pengrajin. Dalam hal ini, solusi alternaif yang ditawarkan adalah dengan mengumpulkan dan melakukan kerjasama dengan praktisi maupun akademisi untuk memberikan pelatihan pemasaran produk gerabah tanah liat dan kemudian melakukan kerjasama dengan stakeholder pemasaran setempat yang terkait untuk melakukan inovasi pemasaran

c. Permasalahan inovasi produk, alternative solusi yang ditawarkan adalah melakukan kerjasama dengan praktisi maupun akademisi terkait untuk melakukan pelatihan dan pendampingan inovasi produk gerabah tanah liat yang sesuai dengan kebutuhan pasar. 


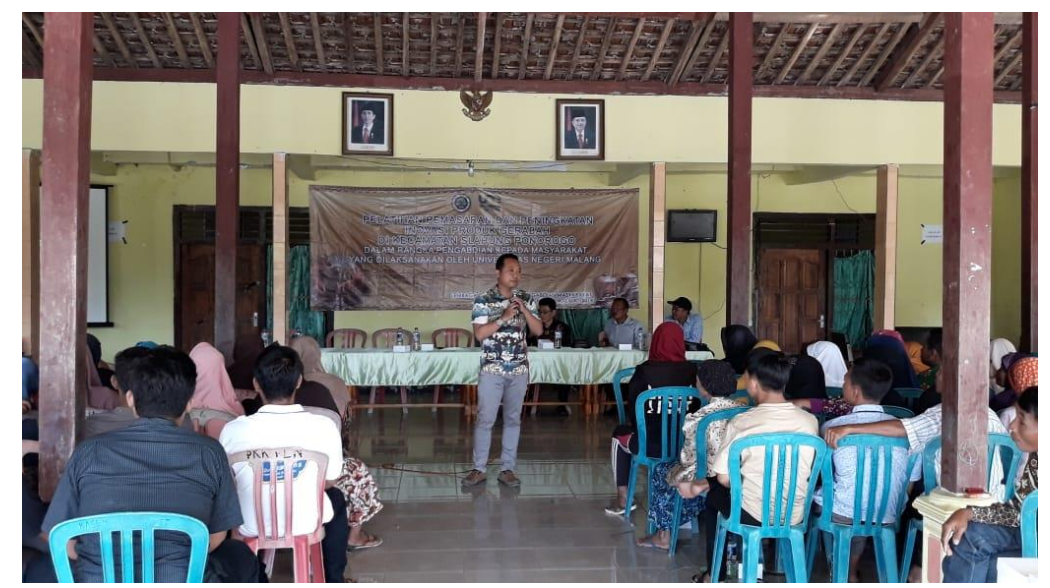

Gambar 4. Kegiatan Pelatihan Pemasaran Produk Gerabah oleh Praktisi Pemasaran

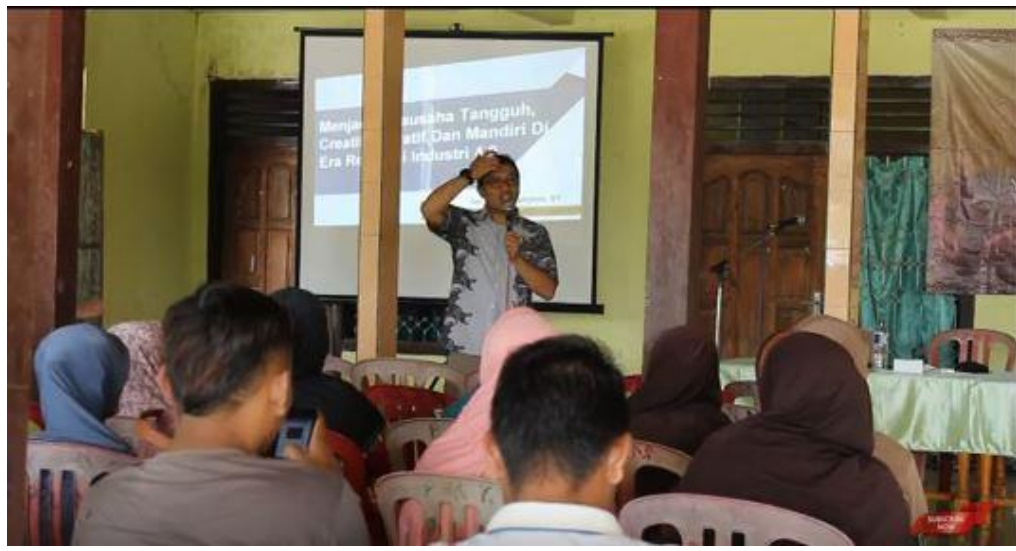

Gambar 5. Kegiatan Pelatihan Inovasi Produk Gerabah Oleh Dinas Perindustrian dan

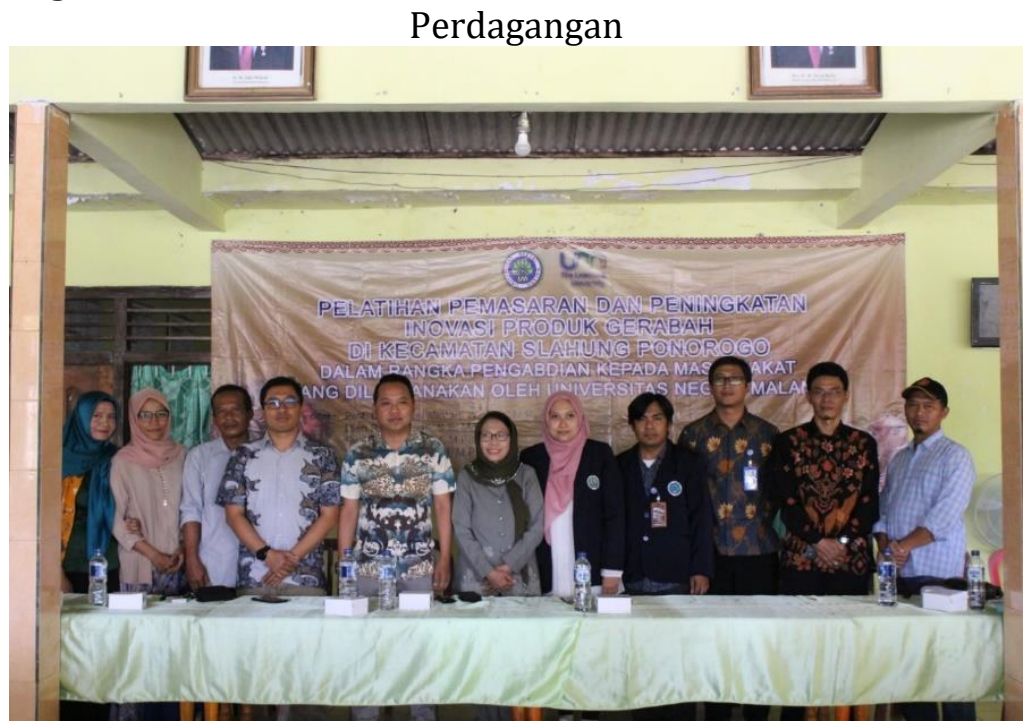

Gambar 6. Kegiatan Pengabdian Masyarakat yang dilaksanakan di Desa Plancungan, Kec. Slahung, Kabupaten Ponorogo

Kerajinan dari tanah liat dan keramik ini sering disebut dengan istilah gerabah dan tembikar. Namun, pada praktiknya kerajinan gerabah tradisional tanah liat mengalami pergeseran. Tidak hanya pergeseran persediaan di pasaran yang semakin menurun karena permintaan masyarakat yang digantikan oleh alumunium, tembaga perak maupun gerabah keramik. Turunnya permintaan ini disebabkan oleh rendahnya kualitas dan inovasi gerabah tanah liat yang dihasilkan oleh pengrajin UMKM gerabah. Sehingga dalam pelaksanaan kegiatan 
pengabdian ini dilakukan dua jenis pelatihan yaitu pelatihan pemasaran dan pelatihan peningkatan inovasi produk.

Hasil dari kegiatan ini adalah terbentuknya komunitas/ kelompok Pra Koperasi yang bernama "Paguyuban Gerabah Plancungan". Selain itu tindak lanjut dari kegiatan pengabdian ini adalah pelaksanaan studi banding ke desa wisata kerajinan gerabah di Kasongan Jawa Barat, dengan melibatkan perangkat desa dan anggota paguyuban.

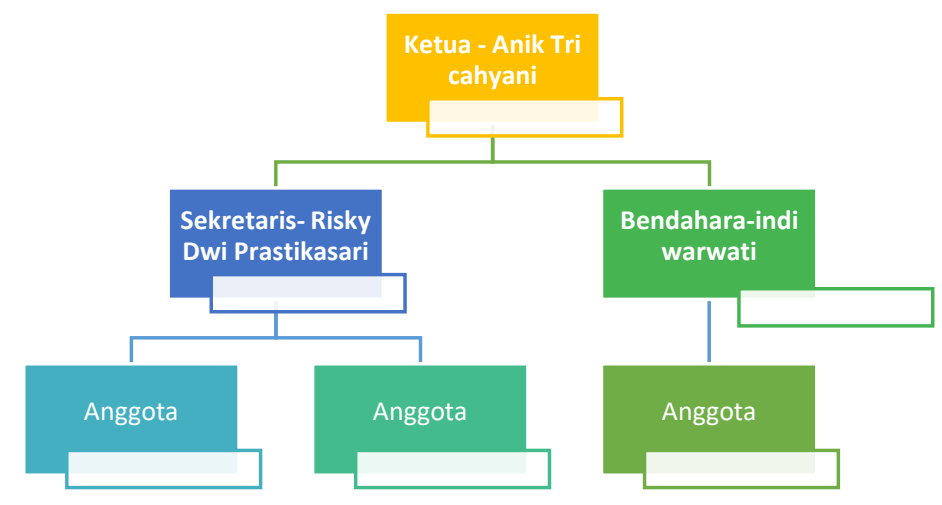

Gambar 7. Struktur Organisasi Paguyuban Gerabah Plancungan

Tabel 1 Jumlah Anggota dalam paguyuban Gerabah Plancungan

\begin{tabular}{|c|c|c|}
\hline NO & Nama Anggota & Keterangan \\
\hline 1 & Mesinah & Anggota \\
\hline 2 & Tukini & Anggota \\
\hline 3 & Mistun & Anggota \\
\hline 4 & Sutiyah & Anggota \\
\hline 5 & Lamiyem & Anggota \\
\hline 6 & Jariyem & Anggota \\
\hline 7 & Sutini & Anggota \\
\hline 8 & Tukinem & Anggota \\
\hline 9 & Murni & Anggota \\
\hline 10 & Sutini & Anggota \\
\hline 11 & Giyah & Anggota \\
\hline 12 & Misiyem & Anggota \\
\hline 13 & Sutiah & Anggota \\
\hline 14 & Siwuh & Anggota \\
\hline 15 & Paikem & Anggota \\
\hline 16 & Sarinem & Anggota \\
\hline 17 & Kotinem & Anggota \\
\hline 18 & Jaitun & Anggota \\
\hline 19 & Boinem & Anggota \\
\hline 20 & Sartini & Anggota \\
\hline 21 & Jemani & Anggota \\
\hline 22 & Tahudi & Anggota \\
\hline 23 & Senen & Anggota \\
\hline 24 & Sukardi & Anggota \\
\hline 25 & Misnatin & Anggota \\
\hline
\end{tabular}




\begin{tabular}{lcl}
\hline 26 & Rumini & Anggota \\
\hline 27 & Boirah & Anggota \\
\hline 28 & Anik & Anggota \\
\hline 29 & Menok & Anggota \\
\hline 30 & Yarman & Anggota \\
\hline
\end{tabular}

\section{PROSES PENGESAHAN BADAN HUKUM KOPERASI}

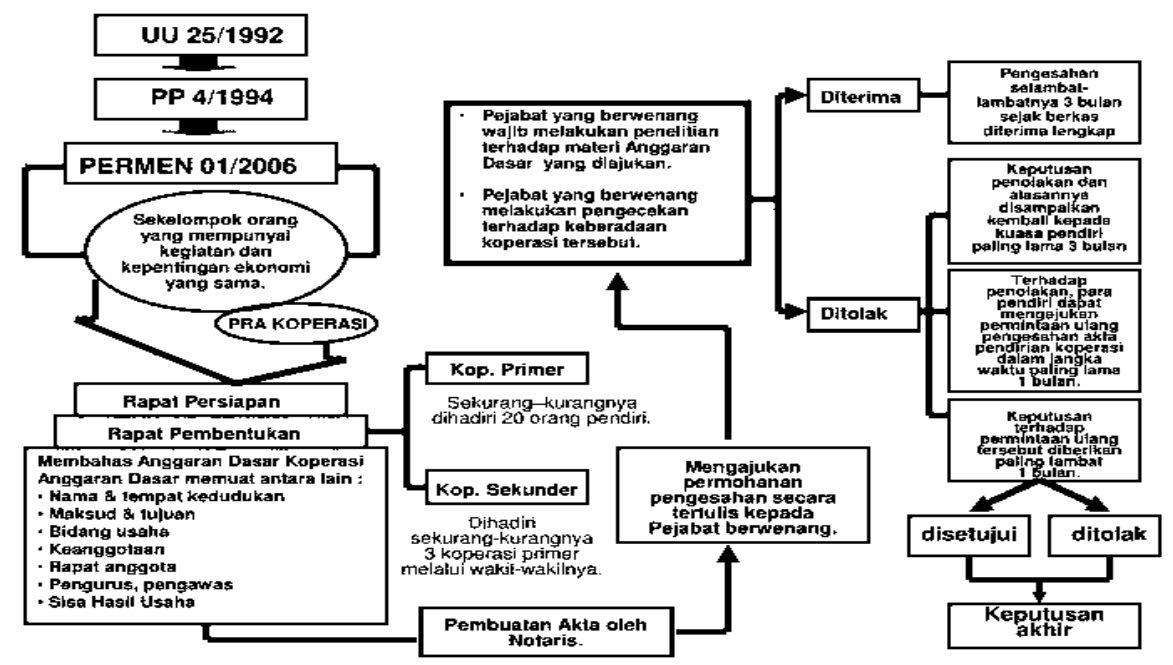

Untuk mewujudkan kemandirian usaha dan permodalan tentu diperlukan usaha yang masih panjang, melihat dalam proses pengesahan untuk menjadi Koperasi sebuah organisasi pra-koperasi akan melalui proses yang bertahap tidak hanya usaha pemikiran namun juga finansial. Sehingga untuk mewujudkan hal tersebut sangat dibutuhkan keterlibatan para perangkat desa, pengrajin, pemerintah daerah, dan masyarakat untuk mewujudkan terbentuknya koperasi gerabah di Kabupaten Ponorogo.

\section{KESIMPULAN}

Kegiatan pengabdian ini dilakukan melalui beberapa tahap yaitu, FGD yang melibatkan pedagang, pengrajin, pemerintah setempat, dan tim pengabdian. Selanjutnya untuk mempermudah koordinasi dan ketersediaan modal melalui FGD tersebut disepakati untuk membuat komunitas/ paguyuban Pra Koperasi dengan nama "Paguyuban Gerabah Plancungan". Berdasarkan survey dan wawancara mendalam terhadap para pengrajin, untuk mengataasi permasalahan pemasaran, dan inovasi yang dialami pengrajin, tim pengabdian mengadakan pelatihan pemasaran produk gerabah dan pelatihan inovasi produk yang dilakukan oleh praktisi pemasaran dari Kabupaten Ponorogo dan dinas perindustrian dan perdagangan di Kabupaten Ponorogo. Pelatihan tersebut tidak hanya dihadiri oleh para pengrajin, namun juga melibatkan para anak muda yangberpotensi untuk meneruskan usaha kerajinan gerabah tersebut.

\section{UCAPAN TERIMA KASIH}

Tim penulis mengucapkan terimakasih kepada Universitas Negeri Malang (UM) dan LP2M UM yang telah memberikan dukungan financial terhadap kegiatan pengabdian kepada masyarakat ini. Serta kepada para perangkat desa yang terlibat dalam kegiatan ini, serta para pengrajin gerabah di tiga desa di Kab. Ponorogo. 


\section{DAFTAR PUSTAKA}

Addien.2010. Praktik Membuat Kerajinan Tanah Liat. Trans Mandiri Abadi.Jakarta.

Departemen Pendidikan Nasional. 2008. Kamus Besar Bahasa Indonesia. Jakarta: Pusat Bahasa.

Glenardi, Glen. 2002. Peran Perbankan dalam Pengembangan Keuangan Mikro. Dalam diskusi kelompok C2 Temu Nasional Bazar Pengembangan Mikro.

https://ekbis.sindonews.com/read/1331120/34/sektor-umkm-jadi-andalan-perekonomian-jatim1534492582 (diakses pada 13 Januari 2019)

https://ekbis.sindonews.com/read/1331120/34/sektor-umkm-jadi-andalan-perekonomian-jatim1534492582 (diakses pada 12 Jauari 2019)

Hubeis, Musa. 2009. Prospek Usaha Kecil Dalam Wadah Inkubator Bisnis. Jakarta: Ghalia Indonesia.

Oka, I.B. 1975. Keramik Tradisional Bali. Denpasar, Sasana Budaya.

Tambunan, Tulus. 2002. Usaha Kecil dan Menengah di Indonesia Beberapa Isu Penting. Jakarta: Salemba Empat.

Tambunan, Tulus. 2009. UMKM di Indonesia. Jakarta: Ghalia Indonesia.

Undang-Undang Republik Indonesia Nomor 20 Tahun 2008 Pasal 3, Tentang Usaha Mikro Kecil dan Menengah.

Kemenperin. Ekspor Tembus USD 25 Juta, IKM Gerabah dan Keramik Hias Masih Prospektif,. 2018. [Online]. Available: (https://kemenperin.go.id/artikel/18610/IKM-Dibidik-Tumbuh-Dua-DigitTahun-2018). 